\title{
TINJAUAN HUKUM ISLAM TERHADAP PENGAWASAN TAMAN NASIONAL KERINCI SEBLAT DALAM UPAYA PELESTARIAN LINGKUNGAN HIDUP DI KABUPATEN KERINCI
}

\author{
Pitriani $^{1}$, Nurasiah ${ }^{2}$ \\ ${ }^{1,2}$ Institut Agama Islam Negeri (LAIN) Kerinci \\ email: pitrianiiainkerinci@gmail.com
}

\begin{abstract}
The environment in Islamic teachings is rooted in the Qur'an. The approach used in this study is sociological juridical. The sample technique that the researcher used in this study was purposive sampling. After the data is classified then analyzed qualitatively, the analysis is not based on mathematical calculations but underlies the reality that is in the field then described in the form of reality. The results of this study include: 1) Human relations as caliphs on earth to their environment must be based on the principle of correct use and avoiding damage. 2) Monitoring of the TNKS forest has not been implemented effectively, this can be known, where there are still activities that can damage the TNKS forest such as encroachment, theft of forest products, illegal logging in the TNKS forest. 3) Constraints in the preservation and supervision of KSNP in Kerinci Regency are: a) constraints that there are still people who do not understand the importance of TNKS forests; b) field conditions or TNKS forests that are easily accessible to encroachers, illegal loggers and theft of forest products; c) lack of officers overseeing the TNKS forest; and d) lack of facilities and infrastructure.
\end{abstract}

Keyword: Islamic Law, Kerinci Seblat National Park, Environmental Preservation

\begin{abstract}
Abstrak: Lingkungan hidup dalam ajaran Islam berakar di dalam Alquran. Metode yang dipergunakan dalam penelitian ini adalah yuridis sosiologis. Teknik pengambilan sampel yang peneliti pergunakan adalah purposive sampling. Setelah data diklasifikasikan kemudian dianalisis secara kualitatif yaitu penganalisaan yang tidak mendasari dengan perhitungan secara matematis tetapi mendasari pada kenyataan yang ada dilapangan kemudian dijabarkan dalam bentuk kenyataan. Hasil penelitian ini antara lain: 1) hubungan manusia sebagai khalifah di muka bumi terhadap lingkungan hidupnya harus berdasarkan atas asas pemanfaatan yang benar dan menghindarkan kerusakan. 2) Pengawasan terhadap hutan TNKS belum terlaksana secara efektif, hal ini dapat diketahui, dimana masih adanya kegiatan-kegiatan yang dapat merusak hutan TNKS seperti perambahan, pencurian hasil hutan, penebangan liar didalam hutan TNKS. 3) Kendala dalam pelestarian dan pengawasan TNKS di Kabupaten Kerinci yaitu: a) masih adannya masyarakat yang kurang memahami akan arti pentingnya hutan TNKS; b) kondisi medan atau hutan TNKS yang mudah dijangkau para perambah, penebang liar dan pencurian hasil hutan; c) kurangnya petugas yang mengawasi hutan TNKS; dan d) kurangnya sarana dan prasarana.
\end{abstract}

Kata Kunci: Hukum Islam, Taman Nasional Kerinci Seblat, Pelestarian Lingkungan Hidup 


\section{PENDAHULUAN}

Lingkungan hidup dalam ajaran Islam berakar di dalam Alquran, mendorong manusia untuk merenungkan alam dan fenomena alam, untuk mempelajari hubungan antara organisme hidup dan lingkungan mereka, untuk membuat menggunakan akal dan untuk menjaga keseimbangan atau proporsi dalam ciptaan Allah SWT .

Lingkungan hidup dianugerahkan Allah SWT kepada manusia, serta makluk hidup lainnya demi kelangsungan dan peningkatan kualitas hidup itu sendiri. Antara manusia dengan lingkungan hidup terdapat hubungan timbal balik yang harus selalu dibina dan dikembangkan agar tetap dalam keselarasan.

Dalam upaya pelestarian lingkungan hidup ini, keberadaan hutan Taman Nasional Kerinci Seblat (TNKS) mempunyai arti yang sangat penting, dimana hutan TNKS mempunyai fungsi dalam pengaturan tata air, pemeliharaan kesuburan tanah, pencegahan bahaya banjir dan erosi, oleh karena itu harus dilakukan suatu upaya untuk melindungi hutan TNKS dalam upaya pelestarian lingkungan hidup itu sendiri.

Luas kawasan Taman Nasional Kerinci Seblat sekitar \pm 1.368 .000 hektar. Secara administrasi termasuk dalam empat Propinsi yang meliputi Propinsi Sumatera Barat, Sumatera Selatan, Bengkulu dan Propinsi Jambi.

Taman Nasional Kerinci Seblat ( TNKS ) dikelola secara intensif, tujuannya untuk mewujudkan sumber daya alam yang berguna bagi perlindungan, bagi ekologi dan sistem penyangga kehidupan, pengawetan keanekaragaman plasma nuftah, pelestarian pemanfaatan jenis dan ekosistem yang menunjang kehidupan dan kesejahteraan masyarakat.

Selain sebagai kawasan pelestarian alam yang mendukung kehidupan berbagai jenis tumbuhan, satwa dan ekosistem, kawasan TNKS juga berfungsi sebagai daerah tangkapan air bagi sungai dan anak sungai yang mengalir kedataran rendah didaerah empat wilayah propinsi atau sembilan kabupaten. Diperkirakan lebih 5 juta jiwa dan 10 juta hektar lahan pertanian tergantung dari kelestarian DAS atau Sub DAS yang berhulu di kawasan hutan TNKS ini.

Dalam upaya melindungi hutan TNKS tersebut dapat dilakukan dalam bentuk pengawasan terhadap hutan TNKS. Dengan adanya pengawasan terhadap hutan TNKS diharapkan kelestarian lingkungan hidup dapat dipertahankan atau dijaga.

Negara merupakan organisasi kekuasaan, yang tidak terlepas dari masalah ketidaktertiban, karena itu memerlukan adanya pengawasan. Di Indonesia masalah pengawasan jelas akan menjadi lebih penting lagi artinya, mengingat disatu sisi Negara Indonesia didalam sistem pemerintahannya menganut sistem negara hukum (rechtstaat) dan 102 
sistem negara kesejahteraan (welfarestate) yang mendambakan suatu masyarakat yang tertib, adil dan makmur, menurut Sitomorong dan Yusuf. ${ }^{1}$ Masalah ketidaktertiban dapat terjadi disegala bidang kehidupan, termasuk dibidang lingkungan hidup.

Pengawasan merupakan bagian dari kegiatan pemerintah yang bertujuan mengusahakan tercapainya kebijaksanaan yang telah digariskan dan berupaya mencegah adanya penyimpangan terhadap objek yang diawasi. Pentingnya pengawasan dapat pula dilihat dari definisi pengawasan yang diberikan Sujamto yaitu "segala usaha atau kegiatan untuk mengetahui dan menilai kenyataan yang sebenarnya tentang pelaksanaan tugas atau kegiatan apakah sesuai dengan semestinya atau tidak", menurut Sujamto. ${ }^{2}$ Untuk menjaga agar tidak terjadinya kegiatan-kegiatan yang tidak sesuai dengan tujuan keberadaan hutan TNKS dalam upaya pelestarian lingkungan hidup, maka pengawasan harus dilakukan terhadap hutan TNKS, karena dengan adanya pengawasan terhadap hutan TNKS diharapkan kegiatan-kegiatan yang merusak hutan TNKS dapat diketahui, dicegah dan ditanggulangi.

Di TNKS diketahui terdapat kegiatan yang dilarang, seperti perambahan, pencurian hasil hutan dan penebangan liar didalam hutan TNKS kegiatan yang dilarang tersebut, dapat merusak hutan TNKS, kegiatan-kegiatan tersebut juga dapat merugikan baik untuk habitat yang berada di dalam hutan TNKS dan juga bagi penduduk yang ada didalam dan disekitar TNKS.

Dalam Al Qur'an, Surat Ar-Ruum ayat 41, yang menjelaskan akibat dari kerusakan oleh tangan manusia : "' Telah nampak kerusakan di darat dan di laut disebabkan karena perbuatan tangan manusia, supaya Allah merasakan kepada mereka sebahagian dari (akibat) perbuatan mereka, agar mereka kembali (ke jalan yang benar). (Al-Qur'an, Surah Ar-Ruum/30: 41)

Kata zhahara pada mulanya berarti terjadinya sesuatu dipermukaan bumi. Sehingga, karena dia dipermukaan, dia menjadi nampak dan terang serta diketahui dengan jelas. Sedangkan kata al-fasad menurut al-ashfahani adalah keluarnya sesuatu dari keseimbangan, baik sedikit maupun banyak. Kata ini digunakan menunjuk apa saja, baik jasmani, jiwa, maupun hal-hal lain, menurut Shihab. ${ }^{3}$

Dalam ayat lain juga dijelaskan kata al-fasad: "Dan apabila ia berpaling (dari kamu), ia berjalan di bumi untuk Mengadakan kerusakan padanya, dan merusak tanam-tanaman dan binatang ternak, dan Allah tidak menyukai kebinasaan". (Al-Qur’an, Surah al-Baqarah/2: 205)

${ }^{1}$ Victor M.Situmorong dan Jusuf. 1994. Aspek Hukum Pengawasan Melekat Dalam Lingkungan Aparatur Pemerintah. Jakarta:Rineka Cipta., hlm. 1.

${ }^{2}$ Sujamto. 1987. Aspek-aspek Pengawasan di Indonesia. Jakarta: Sinar Grafika., hlm. 67.

${ }^{3}$ M. Quraish Shihab. 2002. Tafsir Al-Mishbah. Jakarta : Lentera Hati., hlm. 236. 
Ayat di atas menyebut darat dan laut sebagai tempat terjadinya fasad itu. Ini dapat berarti daratan dan lautan menjadi arena kerusakan, yang hasilnya keseimbangan lingkungan menjadi kacau. Inilah yang mengantar sementara ulama kontemporer memahami ayat ini sebagai isyarat tentang kerusakan lingkungan, menurut Shihab. "Dari beberapa ayat AlQura'an menunjukkan bahwa Agama Islam mengandung prinsip-prinsip etika lingkungan yang merupakan wujud nyata kekuatan moral untuk pelestarian daya dukung lingkungan hidup", menurut Erwin. ${ }^{5}$

Di Kabupaten Kerinci juga terjadi kerusakan lingkungan seperti kerusakan hutan TNKS akibat perambahan, penebangan liar dan juga adanya kegiatan pencurian hasil hutan dalam kawasan TNKS yaitu berupa kayu dan non kayu seperti manau, rotan, getah kayu, dammar dan buah-buahan.

Balai Besar TNKS mencatat luas kawasan hutan yang telah dirambah sekitar 41 ribu hektare. Ini terjadi di empat provinsi wilayah TNKS, yakni Jambi, Sumbar, Bengkulu, dan Sumsel. Namun kawasan perambahan yang paling parah terdapat di Kerinci dan Sungai Penuh yaitu mencapai 20 ribu hektare. Di Kabupaten Kerinci titik perambahan hutan ada di Gunung Kerinci, Gunung Tujuh, Kawasan Masgo di Gunung Raya. Selain itu perambahan liar di Renah Pemetik yang tak kurang dari 3 ribu hektare. Menurut TNKS wilayah Kerinci perambahan hutan di kawasan TNKS tersebut, selain mengambil kayu yang ada, kemudian kebanyakan areal tersebut dijadikan lahan usaha pertanian. ${ }^{6}$

Kegiatan-kegiatan yang dilakukan didalam hutan TNKS tersebut terus berlangsung dari waktu kewaktu, hal ini mengakibatkan kerusakan TNKS yang sangat memprihatinkan. Untuk itu pengawasan terhadap hutan TNKS sangat penting sekali dilaksanakan agar kegiatankegiatan yang dapat merusak hutan TNKS dapat diketahui, dicegah dan ditanggulangi.

Latar belakang para pelaku melakukan perambahan hutan TNKS untuk perladangan atau perambahan Di Kabupaten Kerinci yaitu areal perladangan masyarakat umumnya langsung berbatasan dengan TNKS, komoditi yang diusahakan membutuhkan lahan yang luas untuk budidayanya. Dengan adanya ancaman terhadap hutan TNKS tersebut, dapat menimbulkan akibat negatif yaitu terganggunya kelestarian lingkungan hidup.

Untuk mendapatkan suatu gambaran secara jelas dalam penelitian ini, serta untuk menghindari pembahasan yang terlalu luas, maka dalam hal ini peneliti akan membatasi

\footnotetext{
${ }^{4}$ M. Quraish Shihab, Ibid, hlm. 237.

${ }^{5}$ Muhamad Erwin. 2009. Hukum Lingkungan dalam system kebijaksanaan pembangunan lingkungan bidup. Bandung: PT Refika Aditama., hlm. 1.

${ }^{6}$ http:/ /jambi.tribunnews.com/2017/09/15/foto-perambahan-hutan-tnks-sudah-sampai-pos-1gunung-kerinci, akses 2 Agustus 2018

104 Jurnal Islamika: Jurnal Ilmu-Ilmu Keislaman, Vol. 18, No. 02, Desember 2018, pp. 101-116
} 
perumusan masalah sebagai berikut: 1) bagaimana Tinjauan Hukum Islam terhadap pelestarian lingkungan hidup ?; 2) bagaimana Pelaksanaan pengawasan hutan TNKS Di Kabupaten Kerinci?; dan 3) apakah Kendala dan Upaya dalam pelaksanaan pengawasan TNKS di Kabupaten Kerinci?.

\section{METODE}

Metode yang digunakan dalam penelitian ini adalah yuridis sosiologis, maksudnya disamping pendekatan secara hukum Islam dan peraturan perundang-undangan yang berlaku, juga dilaksanakan pendekatan terhadap anggota masyarakat yang ada hubungannya dengan penelitian ini. Spesifikasi penelitian berbentuk deskriftif yaitu memaparkan data dan fakta yang ditemukan dilapangan yang berkaitan dengan objek penelitian yakni Tinjauan Hukum Islam terhadap pengawasan TNKS dalam upaya pelestarian lingkungan hidup Di Kabupaten Kerinci. Sumber data dalam penelitian ini diantaranya: 1) data primer, data-data yang diperoleh selama turun kelapangan yakni wawancara (interview); 2) data sekunder, data-data yang peneliti peroleh dari penelaahan pustaka dari Alqur'an dan terjemahan, Hadist, ijma ulama, peraturan perundang-undangan dan literatur-literatur yang berkaitan dengan penelitian ini. Sampel yang peneliti pergunakan dalam penelitian ini adalah berdasarkan teknik non-rendom sampling yakni secara purposive sampling yaitu sampel yang dipilih adalah masyarakat yang berbatasan dengan hutan Taman Nasional Kerinci Seblat. Untuk mendapatkan data yang dibutuhkan dalam penelitian ini, peneliti melakukan penelitian lapangan dan penelitian kepustakaan. Dalam penelitian ini, teknik pengumpulan data yang peneliti gunakan adalah observasi, wawancara dan studi dokumen. Dari data yang dikumpulkan, baik itu data primer maupun data sekunder yang selanjutnya diseleksi dan diklasifikasikan. Setelah data diklasifikasikan kemudian dianalisis secara kualitatif yaitu penganalisaan yang tidak mendasari dengan perhitungan secara matematis tetapi mendasari pada kenyataan yang ada dilapangan kemudian dijabarkan dalam bentuk kenyataan.

\section{HASIL PENELITIAN DAN PEMBAHASAN}

\section{Tinjauan Hukum Islam Terhadap Pelestarian Lingkungan Hidup}

Salah satu tuntunan terpenting Islam dalam hubungannya dengan lingkungan, ialah bagaimana menjaga keseimbangan alam/lingkungan dan habitat yang ada tanpa merusaknya. Karena tidak diragukan lagi bahwa Allah menciptakan segala sesuatu di alam ini dengan 
perhitungan tertentu. Seperti dalam firman Nya dalam Q.S. al- Mulk/67, yang artinya: Allah yang telah menciptakan tujuh langit berlapis-lapis. Kamu sekali-kali tidak melihat pada ciptaan Tuhan yang Maha Pemurah sesuatu yang tidak seimbang. Maka lihatlah berulangulang. Adakah kamu lihat sesuatu yang tidak seimbang, Departemen Agama RI. ${ }^{7}$

Inilah prinsip yang senantiasa diharapkan dari manusia, yakni sikap adil dan moderat dalam konteks keseimbangan lingkungan, tidak hiperbolis atau pun meremehkan, sebab ketika manusia sudah bersikap hiperbolis atau meremehkan, ia cenderung menyimpang, lalai serta merusak. Hiperbolis di sini maksudnya adalah berlebih-lebihan dan melewati batas kewajaran. Sementara meremehkan maksudnya ialah lalai serta mengecilkan makna yang ada, Qardhawi. ${ }^{8}$

Keduanya merupakan sikap yang tercela, sedangkan sikap adil dan moderat adalah sikap terpuji. Sikap adil, moderat, ditengah-tengah dan seimbang seperti inilah yang diharapkan dari manusia dalam menyikapi setiap persoalan. Baik itu berbentuk materi maupun inmateri, persoalan-persoalan lingkungan dan persoalan umat manusia, serta persoalan hidup seluruhnya.

Keseimbangan yang diciptakan Allah SW'T, dalam suatu lingkungan hidup akan terus berlangsung dan baru akan terganggu jika terjadi suatu keadaan luar biasa, seperti gempa tektonik, gempa yang disebabkan terjadinya pergeseran kerak bumi, Abdullah. ${ }^{9}$

Tetapi menurut Al-Qur an, kebanyakan bencana di planet bumi disebabkan oleh ulah perbuatan manusia yang tidak bertanggung jawab. Firman Allah swt yang menandaskan hal tersebut adalah Q.S. al-Rum/30: 41, yang artinya: "Telah nampak kerusakan di darat dan di laut disebabkan karena perbuatan tangan manusia supaya Allab merasakan kepada mereka sebahagian dari (akibat) perbuatan mereka, agar mereka kembali (kejalan yang benar)." Selanjutnya Allah awt, berfirman di dalam Q.S. Ali Imran/3: 182. "(Adzab) yang demikian itu adalab disebabkan perbuatan tanganmu sendiri, dan bahwasanya Allah sekali-kali tidak menganiaya bamba Nya."

Di abad ini, campur tangan umat manusia terhadap lingkungan cenderung meningkat dan terlihat semakin meningkat lagi terutama pada beberapa dasawarsa terakhir. Tindakantindakan mereka tersebut merusak keseimbangan lingkungan serta keseimbangan interaksi antar elemen-elemennya. Terkadang karena terlalu berlebihan, dan terkadang pula karena terlalu meremehkan. Semua itu menyebabkan penggundulan hutan di berbagai tempat,

${ }^{7}$ Departemen Agama RI. 2001. Al-Qur'an dan Terjemahnya. Jatinegara: Darus Sunnah.

8 Yusuf Qardhawi. 2002. Ri'ayah al-Biah fi al-Syari'ah al-Islam, terj. Abdullah Hakam Shah, Islam Agama Ramah Lingkungan. Jakarta: Pustaka al-Kautsar., hlm. 235.

${ }_{9}^{9}$ M. Amin Abdullah.2004. Falsafah Kalam di Era Post Modernisme. Yogyakarta : Pustaka Pelajar., hlm. 183. 106 
gangguan terhadap habitat secara global, meningkatnya suhu udara, serta menipisnya lapisan ozon yang sangat mencemaskan umat manusia dalam waktu dekat.

Keberadaan lingkungan bagi kehidupan makhluk pada hakekatnya merupakan suatu syarat mutlak bagi kelangsungan hidup secara menyeluruh. Jika kondisi lingkungannya menunjukan keadan yang baik, berarti lingkungan tersebut menunjang kelangsungan hidup bagi makhluk hidup. Oleh karena itu kualitas atau mutu lingkungan adalah "kondisi lingkungan dalam hubungannya dengan mutu hidup.

Makin tinggi derajat mutu hidup dalam suatu lingkungan tertentu makin tinggi pula derajat mutu lingkungan tersebut dan sebagainya", Rama, Nur dan Masrianty. ${ }^{10}$ Lingkungan hidup dengan seluruh makhluk hidup erat hubungannya Artinya, lingkungan hidup sangat tergantung atas sesama makhluk hidup lainnya. Bahkan secara sentral manusia sebagai pemegang peranan dalam sistem ekologi-pun sangat tergantung kepada keberadaan lingkungannya. Begitu pula dengan lingkungan itu akan tetap memiliki mutu yang baik, tidak lepas pula dari tangan manusia yang berposisi sebagai khalifah fi al-ard. Firman Allah dalam Q.S. al-Baqarah/2: 30, yang artinya: "dan (ingatlah) ketika Tuhanmu berfirman kepada para malaikat, "Aku hendak menjadikan khalifa di bumi." Mereka berkata. "Apakah engkau hendak menjadikan orang yang merusak dan menumpahkan darah di sana, sedangkan kami bertasbih memuja-Mu dan menyucikan nama-Mu?" Dia berfirman, "Sungguh Aku mengetahui apa yang tidak kamu ketahui."

Manusia sebagai khalifa, merupakan pemimpin atau pengatur terciptanya ketertiban dan kedamaian di muka bumi ini. Ia mempunyai tugas memimpin dirinya dan mengelolah lingkungannya dengan baik. Oleh karena itu, lingkungan dalam persepsi agama merupakan tugas pokok manusia dalam memelihara keberadaannya.

Kebaikan atau kelestarian lingkungan hidup tergantung dari kebaikan pemeliharaan manusia. Kelayakan hidup makhluk hidup itu tercipta apabila terdapat upaya mempertahankan diri dan lingkungannya dengan sebaik mungkin. Manusia bertindak dengan baik untuk sesama manusia dan lingkungannya. Arus hubungan timbal balik mengandung makna bahwa lingkungan hidup dengan manusia dengan sebaliknya manusia dengan lingkungannya adalah integratif. Artinya, satu sumber yakni Allah SWT.. Sebagai penciptanya, satu hakekat yakni saling bermanfaat dan satu pengembangan dalam konteks pembangunan kehidupan manusia atau dengan kata lain integrasi kejadian, integrasi kemanfaatan,dan

${ }^{10}$ Bahaking Rama, Fatmawati Nur dan Masrianty.2009. Pengetabuan Lingkungan. Makassar:Alauddin Press., hlm. 8.

Jurnal Islamika: Jurnal Ilmu-Ilmu Keislaman, Vol. 18, No. 02, Desember 2018, pp. 101-116 
integrasi kepentingan. ${ }^{11}$

Sebagai disiplin ilmu yang mengatur hubungan manusia terhadap Tuhannya, hubungan manusia terhadap dirinya sendiri, hubungan manusia terhadap sesama manusia, hubungan manusia terhadap lingkungan hidup di sekitarnya, maka tidak diragukan bila fikih memiliki peran yang krusial dalam merumuskan tata kelola lingkungan hidup yang sesuai dengan hukum-hukum syara'. Dalam bukunya yang berjudul Ri'ayatul Bi'ah fi Syari'atil Islam, Dr. Yusuf AlQardhawi menjelaskan bahwa fikih sangat concern terhadap isu-isu lingkungan hidup ini. Hal ini dapat dibuktikan dengan pembahasan-pembahasan yang terdapat dalam literatur fikih klasik, seperti: pembahasan thaharah (kebersihan), ihya almawat (membuka lahan tidur), al-musaqat dan al-muzara'ah (pemanfaatan lahan milik untuk orang lain), hukum-hukum terkait dengan jual beli dan kepemilikan air, api dan garam, hak-hak binatang peliharaan dan pembahasan-pembahasan lainnya yang terkait dengan lingkungan hidup yang ada di sekitar manusia. ${ }^{12}$

Beliau juga menegaskan, bahwa pemeliharaan lingkungan merupakan upaya untuk menciptakan kemaslahatan dan mencegah kemudharatan. Hal ini sejalandengan maqāsid alsyarīah (tujuan syariat agama) yang terumuskan dalam kulliyāt al-khams, yaitu: hifzu al-nafs (melindungi jiwa), hifzual-aql (melindungi akal), hifzu al-māl (melindungi kekayaan/property), hifzu al-nasb (melindungi keturunan), hifzu al-dīn (melindungi agama). Menjaga kelestarian lingkungan hidup menurut beliau, merupakan tuntutan untuk melindungi kelima tujuan syari'at tersebut. Dengan demikian, segala prilaku yang mengarah kepada pengrusakan lingkungan hidup semakna dengan perbuatan mengancam jiwa, akal, harta, nasab, dan agama. $^{13}$

Dalam konteks pelestarian lingkungan ini, Yusuf Qaradhawi bahkan menegaskan penerapan hukuman sanksi berupa kurungan (At-Ta'zir) bagi pelaku pengrusakan lingkungan hidup yang ditentukan oleh pemerintah (Waliyyul amr), seiring dengan hukum yang terkandung dalam hadis Rasulullah saw: "Perumpamaan orang-orang yang mengakkan hukum Allah dan orang yang melakukan pelanggaran, adalah laksana suatu kaum yang sedang menumpang sebuah kapal. Sebagian dari mereka menempati tempat yang di atas dan sebagian yang lain berada di bawah. Maka orang-orang yang bertempat di bawah, jika hendak mengambil air mereka harus melewati orang yang ada di atas mereka. Maka berinisiatif untuk

${ }^{11}$ Bahaking Rama, Fatmawati Nur dan Masrianty, Ibid, hlm. 8

12 Yusuf Qardhawi. Op., Cit., hlm. 235.

${ }^{13}$ Yusuf Qardhawi. Ibid., hlm. 44. 
membuat lobang pada bagian mereka, agar tidak akan mengganggu orang yang ada di atas. Jika kehendak mereka itu dibiarkan saja, pastilah akan binasa seluruh penumpang kapal, dan jika mereka dicegah maka merekapun selamat dan selamatlah pula orang-orang lain seluruhnya. ${ }^{14}$

Fenomena penggundulan hutan dan sumber daya alam nabati Fikih melarang praktek ini karena berakibat pada kerusakan dan bencana yang mengancam makhluk hidup.

\section{Pelaksanaan pengawasan hutan TNKS Di Kabupaten Kerinci}

Taman Nasional Kerinci Seblat memiliki nilai yang sangat tinggi, baik dalam bentuk kekayaan alam flora maupun fauna, serta keindahan yang terdapat didalam Hutan TNKS. Untuk menjaga hutan TNKS dari gangguan yaitu berupa perambahan, pencurian hasil hutan dan penebangan liar, maka pengawasan mutlak dilakukan. "pengawasan terhadap TNKS dalam arti pengawasan secara keseluruhan yaitu agar pengelolaan TNKS itu sendiri, tertib, terarah dan mencapai sasaran yang baik brdasarkan misi dari keberadaan TNKS.”

Dalam pengelolaan TNKS mengemban misi konservasi sumber daya alam hayati, yaitu:

a. Perlindungan sistem penyangga kehidupan

b. Pengawetan keanekaragaman jenis flora dan fauna beserta ekosistemnya.

c. Pemanfaatan secara lestari, sumber daya alam hayati, dan ekosistemnya.

Adapun gangguan yang terjadi pada hutan TNKS diantaranya berupa:

a. Perambahan hutan TNKS. Masalah perambahan hutan TNKS ini merupakan masalah utama dalam TNKS karena hampir terjadi diseluruh wilayah TNKS dan merupakan masalah yang dihadapi setiap tahunnya.

b. Pencurian hasil hutan TNKS. Pencurian hasil hutan dapat dibagi dalam dua bentuk yaitu: 1) pencurian hasil hutan berbentuk kayu bulat;dan 2) pencurian hasil hutan nir kayu atau non kayu, termasuk satwa dan bunga dari hutan.

c. Penebangan liar. Tindakan menebang pohon didalam kawasan hutan, jika dilakukan tanpa izin dari instansi/pejabat kehutanan yang berwenang, digolongkan sebagai tindakan melawan hukum, termasuk perbuatan penebangan liar dilakukan subjek hukum yang telah memperoleh izin menebang namun melapaui batas/target yang diberikan instansi/pejabat kehutanan yang berwenang.

Didalam pelaksanaan pengawasan hutan TNKS Di Kabupaten Kerinci dalam usaha

14 Yusuf Qardhawi. Ibid., hlm. 41-42.

Jurnal Islamika: Jurnal Ilmu-Ilmu Keislaman, Vol. 18, No. 02, Desember 2018, pp. 101-116 
melindungi dan melestarikan hutan TNKS, kantor BTNKS mengadakan koordinasi dengan pemerintah daerah kabupaten Kerinci, "Pengawasan yang dilakukan terhadap hutan TNKS yaitu dalam bentuk penyuluhan dan penegakan hukum”.

Kemudian koordinasi pengawasan yang dilakukan dengan pemerintahan daerah Kabupaten Kerinci, dilakukan setelah diketahui adanya kegiatan-kegiatan yang dapat merusak hutan TNKS berdasarkan pengawasan yang dilakukan terhadap hutan TNKS. Pemerintah Daerah Kabupaten Kerinci mempunyai program pelestarian TNKS dengan mengacu pada rencana umum tata ruang, maksudnya bahwa pemda mempunyai komitmen untuk pelestarian TNKS, adapun tujuan dari pengawasan TNKS itu sendiri yaitu agar TNKS dapat dilestarikan, pengawasan dilakukan untuk mencegah atau menanggulangi kegiatan-kegiatan yang dapat merusak TNKS.

\section{Kendala dan Upaya dalam pelaksanaan pengawasan TNKS di Kabupaten Kerinci}

Pelaksanaan pengawasan hutan TNKS belum terlaksana dengan efektif, hal ini disebabkan adanya kendalah-kendala yang ditemui dalam pelaksanaan pengawasan hutan TNKS tersebut yaitu :

1. Kurangnya kesadaran sebagaian masyarakat akan pentingnya hutan TNKS

Walaupun peran dan manfaat hutan TNKS begitu besar bagi masyarakat setempat atau masyarakat pada umumnya, namun tidak semua masyarakat mengetahui akan besarnya peran dan manfaat hutan TNKS tersebut. Hal ini dapat kita ketahui dimana masih ada masyarakat (oknum tertentu) yang melakukan tindakan perusakan hutan yakni dengan melakukan kegiatan perambahan, pencurian hasil hutan dan penebangan liat dikawasan TNKS.

Peran serta masyarakat didalam pengawasan kehutanan diatur didalam UU Nomor 41 Tahun 1999 tentang pokok-pokok kehutanan, dalam pasal 60 ayat 2 yang berbunyi: masyarakat dan atau perorangan berperan serta dalam pengawasan kehutanan.

Dari bunyi pasal tersebut dapat kita lihat bahwa masyarakat diharapkan ikut serta didalam pengawasan kehutananan, termasuk disini pengawasan terhadap kelestarian hutan TNKS namun kenyataannya dilapangan masih banyak masyarakat yang malah melakukan kegiatan-kegiatan yang dapat merusak kelestarian hutan TNKS, seperti yang telah penulis uraikan sebelumnya bahwa masih kurangnya kesadaran masyarakat akan arti pentingnya hutan TNKS. 
2. Kondisi kawasan TNKS yang mudah dijangkau para perambah, penebang liar dan pencurian hasil hutan

Keadaan hutan TNKS yang berdekatan dengan pemukiman penduduk, merupakan salah satu kendala yang ditemui dalam pelaksanaan pengawasan hutan TNKS, dimana hutan TNKS tersebut dengan mudah dijangkau para perusak atau para pelaku yang melakukan kegiatan-kegiatan yang dilarang didalam hutan TNKS tersebut, dan disamping itu hutan TNKS medan atau lokasinya berbukti- bukti dan terjal. Sehingga petugas yang akan masuk ketempat terjadinya kegiatan- kegiatan yang dilarang didalam hutan TNKS lebih dahulu mengetahui kedatangan petugas, karena mereka berada pada ketinggian dimana tempat mereka melakukan kegiatan yang dilarang dan disatu sisi seringkali masyarakat akan memberi informasi terlebih dahulu kepada para pelaku tersebut tentang kedatangan petugas. "medan berbukit-bukit sebelum masuk ketempat kejadian perkara, tertentu melewati desa, pelaku berada diketinggian tempat perkara, sehingga lebih mudah melihat para petugas, disatu sisi masyarakat desa akan lebih dulu memberi informasi kepada pelaku"

\section{Kurangnya petugas yang mengawasi kawasan hutan TNKS}

Kendala lainnya yang ditemmui didalam pelaksanaan pengawasan hutan TNKS yaitu kurangnya petugas yang mengawasi hutan TNKS. "Jumlah petugas yang masih kurang untuk mengawasi hutan TNKS dikabupaten Kerinici yang luasnya \pm 215.000 ha" Petugas ini bertugas pada rayon-rayon yaitu gunung tujuh, rayon gunung kerinci, rayon bukit tapan, rayon gunung raya, rayon pungut dan rayon batang merangin.

Dengan kurangnya petugas yang mengawasi hutan TNKS ini, berakibat meningkatnya kegiatan-kegiatan yang dapat merusak hutan TNKS, hal yang sulit sekali bagi petugas dapat mengawasi keseluruhan hutan TNKS yang luasnya \pm 215.000 ha dengan maksimal. Keadaan ini tentu menjadi peluang bagi para perusak hutan TNKS untuk melakukan kegiatan-kegiatan yang dapat merusak hutan TNKS yang tidak dapat terawasi petugas.

\section{Kurangnya sarana dan prasarana}

Untuk menunjang kelancaran berbagai kegiatan didalam pelaksanaan pengawasan hutan TNKS, harus didukung oleh sarana dan prasarana, kegiatan pelaksanaan pengawasan tidak akan berjalan sebagaimana dikehendaki, tanpa didukung oleh sarana dan prasarana yang memadai. Kalau dilihat sarana dan prasarana yang dimiliki oleh Balai TNKS, masih belum memadai 
Upaya-upaya yang dilakukan untuk mengatasi kendala-kendala dalam pelaksanaan pengawasan hutan TNKS adalah sebagai berikut:

1. Dalam mengatasi kurangnya kesadaran masyarakat akan pentingnya hutan TNKS. Untuk meningkatkan kesadaran masyarakat akan pentingnya hutan TNKS, maka petugas BTNKS beserta instansi terkait mengadakan beberapa kegiatan yaitu :

a. Penyuluhan

Kegiatan penyuluhan yang dilakukan dalam upaya memupuk kesadaran masyarakat, dilakukan dalam berbagai bentuk sepert ceramah-ceramah, diskusi atau tanya jawab. "Penyuluhan dilakukan oleh staf BTNKS yang menunjang tugas-tugas rutin petugas BTNKS, staf rayon BTNKS, rutinnya menjalankan tugas, tetapi dia juga diamanatkan memberikan penyuluhan kepada masyarakat.”

b. Pembinaan kelompok pecinta alam

Dalam rangka konservasi sumber daya alam dan lingkungan hidup, terutama yang berhubungan dengan masyarakat, maka kegiatan pembinaan kelompok pecinta alam mempunyai peranan yang sangat penting karena kegiatan ini mencakup pula kegiatan penyuluhan, pendidikan dan penelitan. Tujuan pembinaan cinta alam ini adalah menciptakan masyarakat pencinta sumber daya alam sebagai sumber kehidupan baik moril maupun materil.

2. Kondisi medan atau kawasan TNKS yang mudah di jangkau para perambah, penebang liar dan pencurian hasil hutan

Upaya yang dilakukan dalam mengatasi kendala ini yaitu dilakukan koordinasi dengan instansi-instansi terkait di dalam pengawasan hutan TNKS dan juga dengan masyarakat sekitar, sehingga tindakan-tindakan tersebut dapat dipantau dan ditanggulangi namun untuk mengatasi kendala ini tidak mudah karena para pelaku perambahan, pencurian hasil hutan dan penebang liar lebih menguasai medan atau kawasan TNKS sehingga menyulitkan para petugas yang mengawasi hutan TNKS, masyarakat disekitar atau berbatasan langsung dengan hutan TNKS sangat berperan untuk dapat membantu para petugas, kerjasama ini sangat penting dilakukan dalam mengatasi kendala yang ditemui tersebut.

3. Kurangnya petugas didalam mengatasi pelaksanaan pengawasan hutan TNKS

Upaya yang dilakukan yaitu dengan penambahan petugas yang dilakukan tiap tahunnya, Selain itu upaya yangdapat dilakukan didalam mengatasi kurangnya jumlah petugas yaitu dengan melakukan koordinasi dengan instansi terkait dalam operasi gabungan didalam 
hutan TNKS. "Dalam mengatasi kurangnya petugas dilakukan kerjasama dalam bentuk operasi gabungan yang melibatkan instansi- instansi terkait.

Selanjutnya "Operasi gabungan terdiri dari BTNKS, PEMDA, Kepolisian, KODIM dan biasanya camat setempat, semakin sulit permasalahan semakin banyak tim yang ikut patroli, ketergantungan keadaan.”

\section{Kurangnya sarana dan prasarana}

Seperti yang telah penulis uraikan sebelumnya disamping kurangnya petugas dalam pelaksanaan pengawasan hutan TNKS juga kekurangan sarana dan prasarana. Dalam hal ini upaya yang dilakukan untuk mengatasi kendala kurangnya sarana dan prasarana yaitu dibangun dan diadakan beberapa sarana dan prasarana pendukung antara lain mess jagawana, shekter, menara pengintai, pintu gerbang, papan informasi dan beberapa buah alat komunikasi, upaya lainnya adalah pemeliharaan dan perbaikan terhadap sarana dan prasarana dimaksud, sehingga masih digunakan secara optimal.

Dari keterangan tersebut dapat kita ketahui bahwa upaya yang dilakukan di dalam mengatasi kendala kurangnya sarana dan prasarana yaitu dengan perbaikan dan pemeliharaan serta penambahan yang dilakukan tiap tahun anggaran, juga melakukan kerjasama dengan instansi terkait dengan pemda, diharapkan dengan adanya kerjasama pengawasan biasa berjalan dengan baik.

\section{PENUTUP}

Berdasarkan uraian didalam bab terdahulu, maka diperoleh kesimpulan sebagai berikut: 1) Konsep hukum Islam pada hakikatnya adalah konsep aturan-aturan yang dirumuskan oleh Islam dalam rangka mengatur pemanfaatan yang berorientasi pada kelestarian lingkungan sesuai dengan tuntunan Al-Qur'an dan Hadis. Hubungan manusia sebagai khalifah di muka bumi terhadap lingkungan hidupnya harus berdasarkan atas asas pemanfaatan yang benar dan menghindarkan kerusakan. Kesadaran akan tata kelola lingkungan hidup sebagaimana yang sudah digariskan oleh hukum Islam perlu ditanamkan kepada setiap pribadi muslim, dan menjadi tanggung jawab bersama, lebih-lebih pemerintah sebagai pemegang regulasi dalam rangka menjaga dan melestarikan lingkungan hidup dan mengantisipasi dampak kerusakan lingkungan. 2) Pengawasan terhadap hutan TNKS belum terlaksana secara efektif, hal ini dapat diketahui, dimana masih adanya kegiatan-kegiatan yang dapat merusak hutan TNKS seperti perambahan, pencurian hasil hutan, penebangan liar didalam hutan TNKS. 3) Kendala 
dan upaya dalam pelestarian dan pengawasan TNKS di Kabupaten Kerinci yaitu: a) kendala masih adannya masyarakat yang kurang memahami akan arti pentingnya hutan TNKS, upaya yang dilakukan dalam hal ini adalah dengan meningkatkan penyuluhan, pembinaan kelompok pecinta alam;b) kendala kondisi medan atau hutan TNKS yang mudah dijangkau para perambah, penebang liar dan pencurian hasil hutan, upaya yang dilakukan yaitu dengan melakukan kerja sama dengan masyarakat sekitar, agar mereka dapat membantu, dengan cara memberikan informasi kepada petugas tentang adanya kegiatan yang dilarang sehingga kegiatan-kegiatan tersebut, dapat dipantau dan ditanggulangi; c) kendala Kurangnya petugas yang mengawasi hutan TNKS, upaya yang dilakukan yaitu dengan penambahan petugas yang dilakukan tiap tahunnya, selain upaya yang dilakukan didalam mengatasi kurangnya jumlah petugas dengan melakukan koordinasi dengan instansi terkait dalam pengawasan terhadap hutan TNKS; dan d) kendala kurangnya sarana dan prasarana, upaya yang dilakukan yaitu dengan pembangunan dan pengadaan beberapa sarana pendukung antara lain mess jagawana, shelter, menara pengintai, pintu gerbang, papan informasi, upaya lainnya adalah pemeliharaan dan perbaikan terhadap sarana dan prasarana yang dimaksud, sehingga bisa digunakan secara optimal.

\section{REFERENSI}

Departemen Agama RI. 2001 Al-Qur’an dan Terjemahnya. Jatinegara: Darus Sunnah.

Bahaking Rama, Fatmawati Nur dan Masrianty.2009. Pengetahuan Lingkungan. Makassar: Alauddin Press.

Bambang Sunggono. 1998. Metodologi Penelitian Hukum, Jakarta: Raja Grafindo Persada. Jakarta.

Dann Sugandha. 1989. Pengantar Administrasi Negara. Jakakarta: Inter Media.

Daud Silalahi. 2001. Hukum Lingkungan; Dalam Sistem Penegakan Hukum Lingkungan Indonesia. Bandung: Alumni.

Dwi Sutantohadi. buku rencana pengelolaan TNKS Tahun 1995-2019

Indonesia. Undang-Undang Nomor 32 Tahun 2009 Tentang Perlindungan dan Pengelolaan Lingkungan Hidup

Undang-Undang Nomor 5 Tahun 1990 tentang Konservasi Sumber Daya Alam dan Ekosistem 
. Undang-Undang Nomor 41 Tahun 1999 Tentang Pokok-Pokok Kehutanan Indonesia. Undang-Undang Nomor 32 Tahun 2009 Tentang Perlindungan dan Pengelolaan Lingkungan Hidup

. Undang-Undang Nomor 5 Tahun 1990 tentang Konservasi Sumber Daya Alam dan Ekosistem

. Undang-Undang Nomor 41 Tahun 1999 Tentang Pokok-Pokok Kehutanan Lembaga Ilmu dan Dakwah Publikasi Sarana Keagamaan, Ensiklopedi Hadits Kitab 9 Imam, Lidwa Pustaka.

Mochamad Indrawan, dkk. 2007. Biologi Konservasi. Jakarta: Yayasan Obor Indonesia.

Muhamad Erwin. 2009. Hukum Lingkungan dalam system kebijaksanaan pembangunan lingkungan hidup. Bandung: PT Refika Aditama.

Mujiono Abdillah. 2001. Agama Ramah Lingkungan Perspektif Al-Qur'an. Jakarta: Paramadina.

M. Amin Abdullah. 2004. Falsafah Kalam di Era Post Modernisme. Yogyakarta : Pustaka Pelajar.

M. Quraish Shihab. 2002. Tafsir Al-Mishbah. Jakarta : Lentera Hati.

Ridwan. 2016. Hukum Administrasi Negara edisi revisi. Jakarta: Rajawali pers. Salim, H.S. S.H, M.S. 1997.Dasar-dasar hukum kehutanan. Jakarta: sinar grafika.

Siti Sundari Rangkuti. 2005. Hukum Lingkungan dan Kebijaksanaan Lingkungan Nasional, Airlangga University Press.

Slamet Riyadi. 1998. Ekologi Ilmu Lingkungan Dasar-dasar dan Pengertiannya. (Surabaya: Usaha Nasional.

Sujamto. 1987. Aspek-aspek pengawasan Di Indonesia. Jakarta: Sinar Grafika.

Pembahasan Makalah, Optimalisasi Pemanfaatan Sumber Daya Alam TNKS untuk mendukung pembangunan ekonomi rakyat.

Peter Mahmud Marzuki. 2010. Penelitian Hukum, Jakarta: Kencana.

Takdir Rahmadi. 2011. Hukum Lingkungan Di Indonesia. Jakarta: Rajawali Pers

Victor M.Situmorong dan Jusuf. 1994. Aspek hukum pengawasan melekat dalam lingkungan aparatur pemerintah. Jakarta:Rineka Cipta.

Wiratno, dkk. 2004. Berkaca di Cermin Retak; Refleksi Konservasi dan Implikasi Bagi pengelolaan Taman Nasional. Forest Press.

W.J.S. Poerdarminto. 1993. Kamus Umum Bahasa Indonesia Jakarta: PN Balai Pustaka.

Yusuf Qardhawi. 2002. Ri'ayah al-Biah fi al-Syari'ah al-Islam, terj. Abdullah Hakam Shah, Islam Agama Ramah Lingkungan. Jakarta: Pustaka al-Kautsar. 
Pitriani1, Nurasiah2

Zainuddin Ali. 2009. Filsafat Hukum. Jakarta: Sinar Grafika. 